\title{
植物工場における葉菜を対象とした自動化すべき作業とそうでない作業
}

\author{
小倉東一 \\ 株式会社グッドゴール 520-0531 滋賀県大津市水明 1-13-15
}

\section{Operation Should be Automated and not so in Plant Factory for Leafy Vegetables}

\author{
Touichi OGURA \\ Goodgoal Inc, 1-13-15 Suimei Otsu-shi, Shiga 520-0531, Japan
}

\begin{abstract}
The first plant factory in Japan was built more than 20 years ago, and industrial stage of plant factory moves to the development stage from the earlier stage. In the meantime, various automation systems have been developed for the purpose of increasing harvests, saving labor, or decreasing the workload. In this review, we examine these subjects and the range of automation devices, and look at examples of some of the related problems that companies have faced to date. Currently, the amount of time required to produce one leafy lettuce in an artificial plant factory is estimated to be 2.2 minutes. With full mechanization, this time will be reduced to 0.3 minutes. However, the investment in equipment is limited when economic efficiency is taken into consideration. The candidates for mechanization should be carefully selected so as to be compatible with shipping operations; for example, systems that involve less leaf picking and packaging, and fewer cleaning and sterilization operations for cultivation instruments and tools used in the production of 10,000 or fewer lettuces per day.
\end{abstract}

Keywords: automation system, cultivation instrument, fewer cleaning leafy lettuce, packaging production, plant factory, saving labor, sterilization operation

\section{はじめに}

国内で初めて植物工場として, われわれの目にすることがで きたのは 1985 年つくば科学博における日立製作所が出展し た施設である ${ }^{11}$. 建物の中でも野菜を作ることができる, 工場 で野菜が作れる時代が来たのだと，驚きをもって迎えられた。 当初登場してきた完全人工光型から, その後太陽光を併用 する太陽光併用型などへの展開も拡がるなど, 20 数年を経 過し, 植物工場の名前も良く知られ, 今日では 50 を越える営

2011 年 1 月 10 日受付 2011 年 2 月 24 日受理

Corresponding author: Touichi Ogura (ogura11@nike.eonet.ne.jp)
業運転施設が稼働するなど, 黎明期から発展期にさしかかっ てきた感がある.この間さまざまな開発や取組がなされてきた が, 一つの方向性として自動化がターゲットになっていた.こ れは, 限定したスペースでより収量増を実現する方策として, あるいは軽作業栽培体系構築の目的に由来しているもので, 工場というネーミングがもたらす当然な流れであったともいえ る. しかしながら, 生産システムの評価として, 究極的に求め られる経済性に十分な解を与えるところまでには, 至っていな い. そんなところから,これまで各社で取り組まれた例を基に, 今日的にいかにあるべきかを考えてみたい.

収量増の自動化スペーシングは役割終えた

ここでいう植物工場は葉菜の生産プラントであり, その優劣 を決めるのに, 生産能力の高さが問われてくる. つまり, より少 
ないスペースで, よりたくさんの株数の生産が可能になる設備 が求められ, 各社がまず取り組んだのがスペーシング装置で ある. レ夕スの場合, 播種から収穫まで 40 日程度要するが, 収穫前の草丈は $25 \mathrm{~cm}$ にもなり, 株間も, その程度確保した 方が株張りもよく株重も増加する. しかし，育苗ステージにお いての草丈は $2 \sim 3 \mathrm{~cm}$ 程度で, 株間は隣接株と接触するぐ らいでも問題はない，栽培スペースを有効活用するために, 育苗初期は株間を詰めて密植し, 生育が進むにしたがって 株間を拡げることができれば，面積あたりの栽培株数は増え， 結果的に収穫株数も増加する. この概念は, もともと施設園 芸に㧍ける水耕プラントでは, 既に実用化され普及している手 法である. 例えばミツバの水耕栽培では, 栽培パネル $(60 \mathrm{~cm}$ $\times 90 \mathrm{~cm}$ ) を育苗用, 栽培用の 2 種類を準備し, 穴数 ( 植え 付ける株数)を 120 穴, あるいは 48 穴と変えることによって 結果的に株間を変更している, 植替えの作業は発生するが, 栽培株数を増加させる標準的な作型体系となり定着してい る.

植物工場の場合は, これらの既存技術概念を念頭に置き ながら, 自動化システムとして, より効率的生産を目指し開発 がなされていった. 代表的な事例として, 太陽光併用型では あるが, スウエーデンのスエドポニックや ${ }^{2)}$, 川鉄ライフ (現在 の JFE ライフ $)^{3)}$ が取り組んだ栽培用ガッター (樋) が, 定植 側から収穫側に移動する方式がある. 樋は搬送機構で, 毎 日前方に送りだされ, 生育初期, 中期, 後期と 3 段階程度送 り出しピッチを変え, 結果として樋間のピッチが拡がり株間も 拡がる方法である. 送り出しピッチを変えることによって前方方 向にのみピッチが変わるが, 樋内に植わっている株と隣接株 の間,つまり左右のピッチ (株間 ) は変わらない 1 軸スペーシ ング法と呼ばれるもので, その手法を用いない場合に比較し 20 〜 30\%の株数増が可能である.

これに対し, 前後方向だけでなく左右方向も株間を拡げ る 2 軸スペーシング法に取り組んだ例もある. 太陽光併用型 施設でのホウレンソウで出光興産 ${ }^{4-6)}$, レタスで夕バイエスペッ ク7)などの事例はあるが実用化に至っていない. 1 軸に比較 して, 左右株間も調整できることから, さらに約 30\%の密植化 が可能となるなど効果はあるが, 2 軸可変対応のために, ロボ 下利用などメ力機構の複雑化と施設費高は避けられない.

1995 年には高柳等による蛍光灯利用多段型システムが登 場し ${ }^{8)}$, 多層化による面積有効利用の方式が導入されると, このスペーシング利用による密植化が方向転換せざるを得な い状況となってきた．前述の事例は，栽培ベッド部を平面利 用するがゆえに，重要であった技術であり，構造的にも可能と なった方法であった. しかし，多段化によって栽培株数を数倍 とすることが可能になったことからメカ機構を駆使しても 20〜 $70 \%$ 程度の株数増では, 多段化によって 10 倍にも株数が増
加するのに比較し，あまり意味を持たないものとなったからで ある.もちろん多段化においても当初の育苗ステージから生 育ステージ迄を同じ株間で栽培することは総植付株数の減少 を招き不合理であるが，施設園芸で活用されている育苗パネ ルと栽培パネルを使い分けることで中間移植の作業は必要で はあるものの, 手作業介在による 1 軸スペーシングを実施し株 数減とならない状況に持ち込める.

2000 年に M 式水耕研究所が納入したアーバンファーム (千葉 ) の蛍光灯利用多段型植物工場に打いては, 湛液式 ベッド上に栽培パネルを浮かせ, 収穫側パネルを取り出し,で きた空きスペースへ他端の定植側からパネルを手で押してや るフローテイングシステムと呼んでいる従来の水耕プラントで採 用されている劝不要の方式が導入され，スペーシングシステ ムにおけるメカ利用から手動利用へと舵が切られた，その後， 太陽光併用型の平面利用に执いても JFE ライフは, フローテ イングシステムを採用し, 従来の樋利用によるスペーシング機 構を廃止している. このように単なる収量増目的のメカによるス ペーシングは, 存在価值を消失していると云える.

収量増のための自動化スペーシングは役割を終えたと断定 したが,これはどちらかというと太陽光併用型に軸足を置い た視点であり, 完全人工光型においては, 同様に言い切るの は早計であるかも知れない. 多段化によって垂直方向に栽培 ベッドが伸び, その高さが $5 〜 10 \mathrm{~m}$ にもなってくると, 高所作 業を強いられることになる. 対応としては, 途中に作業用デッ キや床を設置し, 人が栽培ベッドに直接アクセスできる高さに 分割した複数フロアー構成で対処する方法や, 高所作業用 ローリングタワーを活用する方法が既設施設では用いられて いる. 本年大阪府立大学に新設される植物工場研究セン夕 一においては, ピッキングロボットを活用し栽培トレイを上部から 順次 $1 \mathrm{~F}$ 部分まで移動させ, 作業は常に $1 \mathrm{~F}$ で行う手法の取 組が計画されている. 高さ方向の棚間隔を 3 段階とし, 下部 になるほど棚間隔が拡がる縦型スペーシングとも呼べる構成 が採用されており，効用性や経済性などの実証研究が展開 される予定で, これらの動向が注目される.

\section{レタス栽培の 1 株あたり総作業時間は 2.2 分}

自動化のもう一つの目的である軽作業化や省力化の観点 から考えてみたい. 植物工場における栽培品目として実用化 されているのはレタス・フリルレタス・サラダ菜・サンチュ・ホウ レンソウ・アイスプラントやバジル・ルッコラ・イ㚈アンパセリの ハーブ類など, 生食サラダ素材として供用される葉菜に集約 されている. これら葉菜は, 一株として株のまま収穫される栽 培パターンで, 栽培から収穫までの作業形態は, 果菜などに 比して, 比較的単純かつ短時間で終えられる特徵を有してい 
る. すでに 20 年の経営実績を持つ完全人工光型植物工場 ハイテクファームでは, レタス類日産 1,000 株の生産で, パート 作業員 6 名の 6 時間勤務で, 播種から出荷までの一連の作 業をこなしている. ここでは包装など出荷調整段階の機械化 はしているが, 栽培に関わる自動化設備の導入は無い. 1,000 株の生産でも 36 時間で対処しており, 1 株あたりの所要時間 は 2.2 分である. パート時給を 800 円としても, わずか 29.3 円 の作業費しかかかっていない. 作業終了時の道具の清掃や 消毒作業など雑作業を含めてのものであり, 試行錯誤と習熟 を経てたどり着いた形態かも知れないが, 意外と時間を要し ていない現実がある.

ハイテクファームでの各工程別作業時間の詳細デー夕は不 詳であるが，工程別作業時間が発表されている中原等による 九州電力 ${ }^{9,10)}$ での事例を Fig. 1 〜 Fig. 3 に示した. 完全人 工光型レタス栽培の主要工程自動化システムとして実験的に 取り組まれたもので, $1,000 \mathrm{~m}^{2}$ 平面栽培施設で日産 1,000 株 のプラントである. Fig. 2 に工程毎に配備された機械類が示 されているが, レタス自動化システムとしてオリジナル開発され たもので, 中でもロボット活用での栽培バーやスペーシング装 置が目新しい. 作業時間結果を Fig. 3 に示している. 各工程 別の作業時間が示されており, 株間調整と収穫〜包装・梱 包の出荷調整工程に時間の大半が取られている. 日産 1,000 株で機械化前での合計作業時間は, 3,175 分で, 1 株あたり は 3.2 分である. 人員換算で見ると 8 時間勤務で, 6.6 人, 6
時間勤務だと 8.8 人となる. 前述のハイテクファームでは，習 熟度を上げた結果 2.2 分／株に到達したと考えられ，それよ り約 1 分多いが, 標準的な作業時間と考えていいと思われる これを各工程を自動化することによって $91 \%$ 減の 288 分 $(0.3$ 分／株 ) にまですることができたというデータである. 作業の 大半を占めていた株間調整と収穫〜包装・梱包工程の機械 化による大幅省力化が効果につながっており機械化による効 果は顕著である. しかし, 実用化まで至っていないのは, 設備 投資額の負担増が敬遠されているからであろう.

\section{規模や目的に応じた自動化}

自動化を考える場合, 生産規模をどう想定するかで大きく 変わってくる. 1990 年代, 完全人工光植物工場の平均規模 は日産 1,000 株程度であったが, 1990 年代後半から 2000 年代に入ると 10,000 株という大型施設も登場してきた. 2 か 所ある 10,000 株の大型施設は, いずれも関西圈であるが, 販売先は関東圈まで市場として考えないと別ききれない現状 である. 輸送は鮮度保持を考慮しクール便活用が一般的で, その場合の輸送コストは 1 株あたり $20 〜 25$ 円にもなっている と聞くが, 輸送の時間的・経済的負担は少なくない. このよう な現状から生食サラダ素材生産の植物工場は, 消費地近く で 1,000 株程度, せいぜい 3,000 株まで程度で地域での消 費量に応じた生産を行う中小規模分散型施設の方向が国内

\section{○設備構成図}

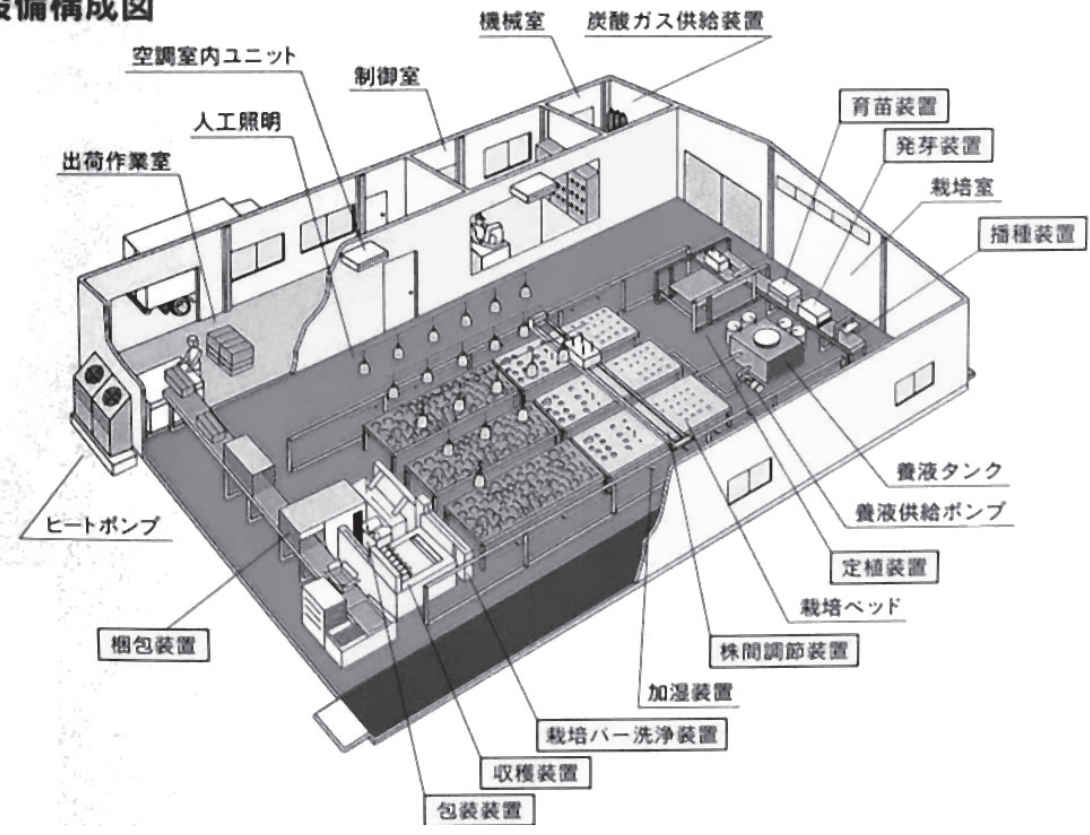

Fig. 1 Schematic diagram of artificial type plant factory (By permission of Kyushu Electric Power Co., Inc.) 

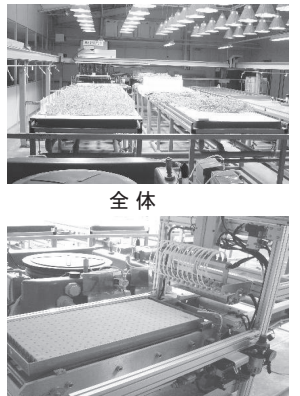

播種装置

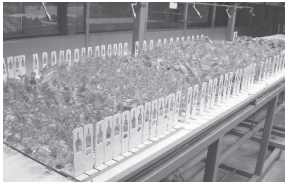

栽培バー

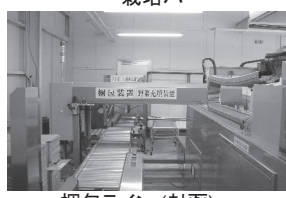

棝包ライン (封函)

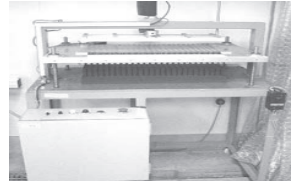

ウレタンかッター

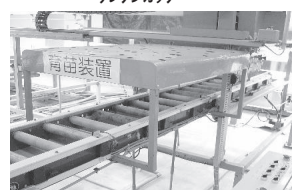

育苗装置

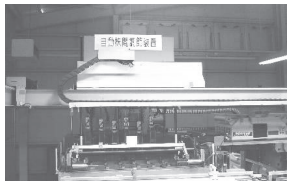

株間調節装置 $($ スペーシシグ $)$

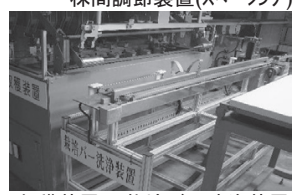

収穫装置 栽培バー洗浄装置

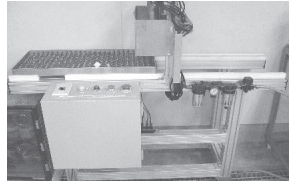

穴あけ装置

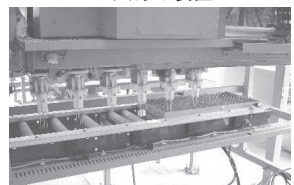

定植装置

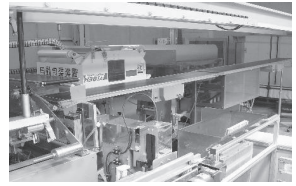

包装ライン

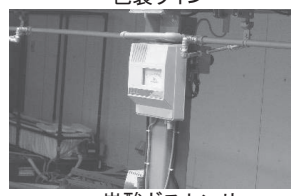

炭酸ガスセンサ

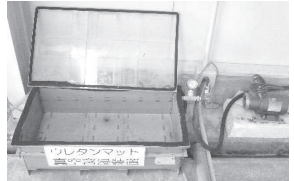

真空含水装置

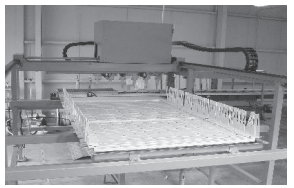

育苗ライン

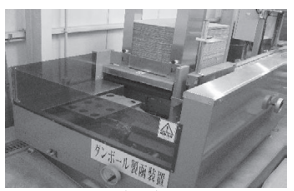

ダンボール製函

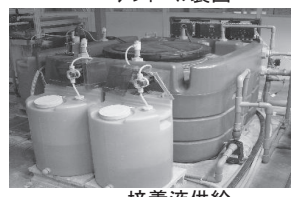

培養液供給

Fig. 2 Automatic machines and apparatuses in leafy vegetable production (By permission of Kyushu Electric Power Co., Inc.)
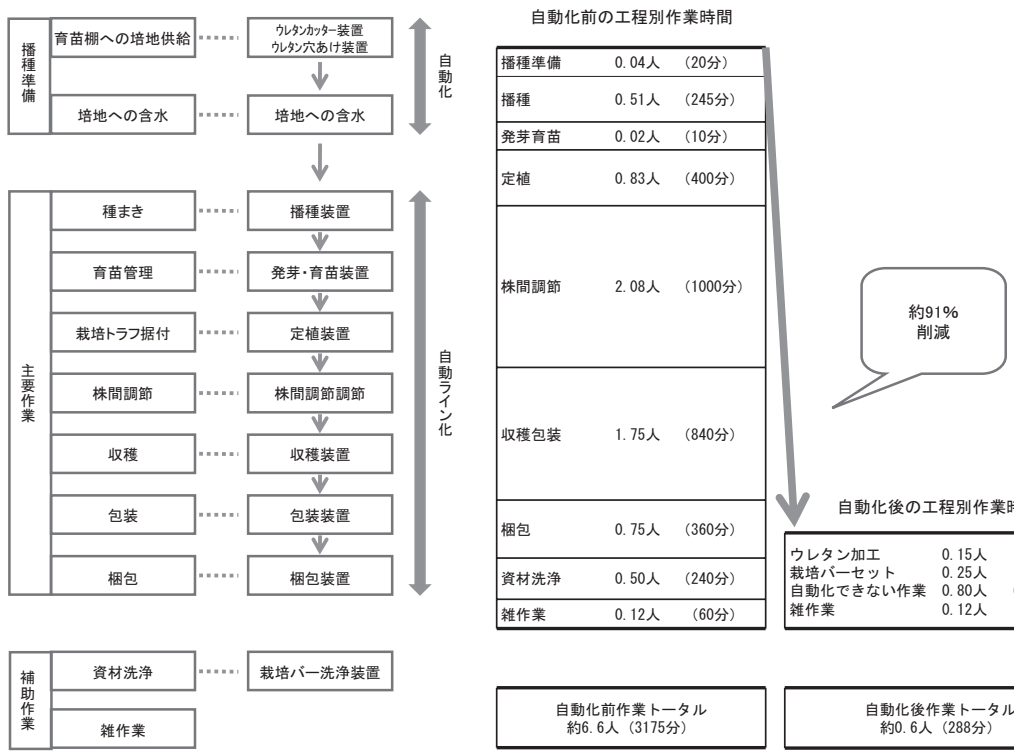

自動化後作業トータル 約 0.6 人 (288分)

Fig. 3 Operating hours in each process and effect of automation (By permission of Kyushu Electric Power Co., Inc.)

における将来像ではないかと筆者は考えている.

1,000 株であれば出荷調整用機械だけでもいいだろうが, その 10 倍の 10,000 株となると, 毎日栽培パネル $(600 \mathrm{~mm} \times$ $900 \mathrm{~mm}) 500$ 枚程度の処理が必要で, 播種機, 定植機, 収
穫機, 計量梱包機, 洗浄機など,人手がかかる工程への自 動化機器の必要性は増加してくる.

また自動化の目的を明確にすることも重要である ${ }^{10)}$. 収量 増なのか, 省人化や作業負荷軽減の軽作業化なのか, ある 
いは作業の安定性・安全性を追いかけるのか, ともすれば経 済性指標で一刀両断に決着をつけがちになるが, オーナーや 地域特性から, もっと大事にしたい側面が設定される場合もあ るであろう. かつて農業生産現場は, $3 \mathrm{~K}$ の代表のようにいわ れてきたが，植物工場はそれを払拭した環境であるとされて いるが, 毎日 500 枚のパネルを冷たい水で洗浄し, 消毒・乾 燥させる作業は荒仕事であるし, 来る日も来る日も, その作業 がある. 機械化による作業負荷軽減は考えて然るべきである.

また障がい者や高齢者を作業に従事させたいというニーズ も高齢化進展に伴い多くなってくると考えられるが, これらの 人達の作業をアシストするロボットやデバイスなど, 新たな視点 を盛り込んだ自動化も求められてきている. 前出の大阪府立 大学「植物工場研究センター」では, このようなニーズに対 応する目的で, ユニバーサルデザイン型植物工場の取組が始 められるなどの動きも現実化してきており，成果が期待されて いる.

\section{自動化すべき作業とそうでない作業}

限りなく自動化を図った例として少し古くなるが 1990 年代 後半に出光興産が太陽光併用型でのホウレンソウ栽培に取り 組んだものがある ${ }^{5)}$. 全工程の自動ライン化による省人化, 2 軸スペーシングによる収量増を目指したホウレンソウの年産 70 tの施設で, パイロットプラント建設し積極的な展開がなされた が, 社内事情から事業化には至らなかった. 専用ロボッ開発 を含め, 播種から出荷まで全工程のライン化を指向したもので ある. Fig. 4 にプラント全体図を, Fig. 5 に構成機器の一部を 示した. ロボットハンド部のチャッキング性を考慮し栽培かップ の使用や, 2 軸スペーシングのために 2 回の移植を行うが,
根が絡まないように噴霧水耕方式を採用するなど専用ロボット 開発を含め斬新な取組が当時注目を浴びた. 今日的にも, そ の開発の視点やアプローチは参考になる点も多い. しかし全 工程をライン化し直列につないだシステムでは, 例えば生育遅 れや生育障害などがライン途中で発生した場合でも, それら がライン終端まで来ないと取り出せないとか, 生育遅れでもライ ンはそれとは関係なく収穫ラインにやってきて, 規定株重に満 たない物も混在し, 本来一袋に一株梱包であるが, 二株入れ る対応をせざるを得なくなり, 販売数量減を招くなどの経済的 損失は無論のこと, 生育状況とは関倸なく動作するメカ機構 の硬直したシステムでの運営による弊害面が表面化してくる 懸念がある. また作目変更の場合, 夕夕卜時間や装置チューニ ング作業が必要となるが, かなり大がかりな作業となるなど大 変で, 工業品対象とした概念を持ち込んでも最適解にならな い点に留意すべきである. 言葉を変えると連続ライン化はリス クも大きく融通性に欠け, 全工程の自動ライン化はやめ, 部分 的工程の自動化に絞るべきである.

一般の施設園芸における自動化, 機械化として, 栽培工 程への導入は, 播種・定植あるいは移植などに一部工程に 限定し, 最も時間を要している下葉取りなどの出荷調整作 業, 包装・梱包作業など収穫後の作業を機械化することに集 中している. 水耕ミツバ生産業者の事例を Fig. 6 に示した. Table. 1 に筆者の考える葉菜に打ける機械化すべき工程と そうでない工程を示したが, やはり費用対効果の経済性尺 度 ${ }^{11)}$ からは限定した部分への導入, どちらかというと収穫後 工程の機械化という結論になるのではなかろうか.

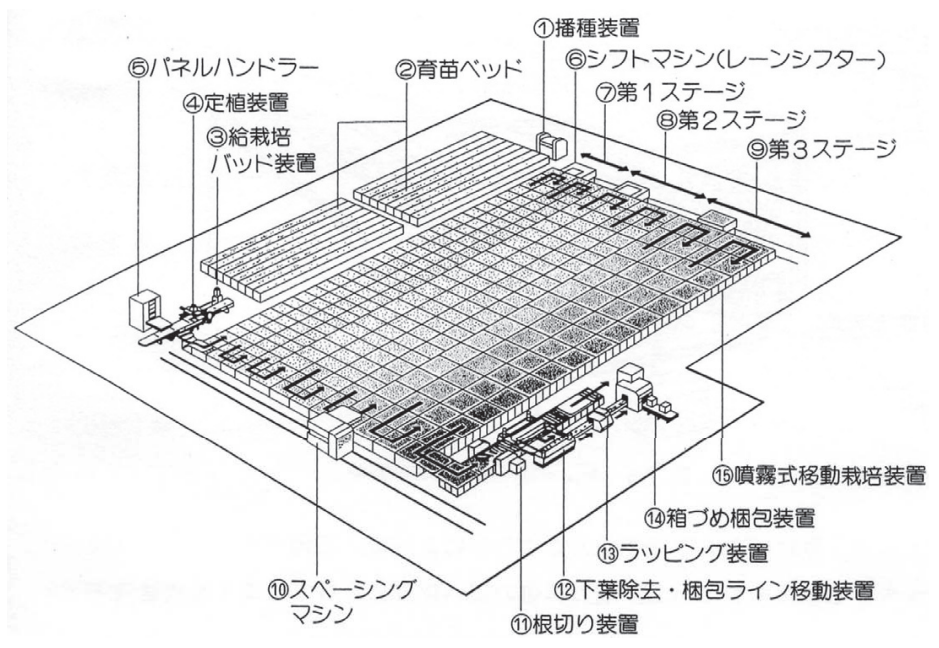

Fig. 4 Schematic diagram of automated plant factory (By permission of Idemitsu Kosan Co., Ltd.) 


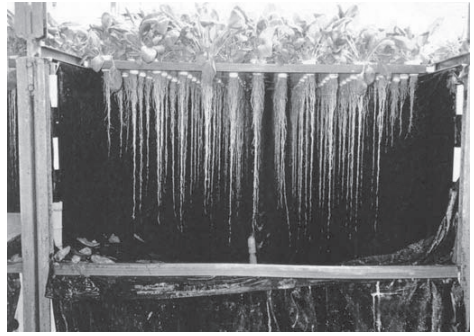

移植時根が絡まないように噴霧式水耕採用

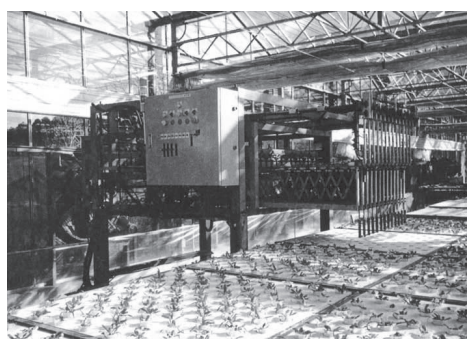

(10中間移植口ボット1

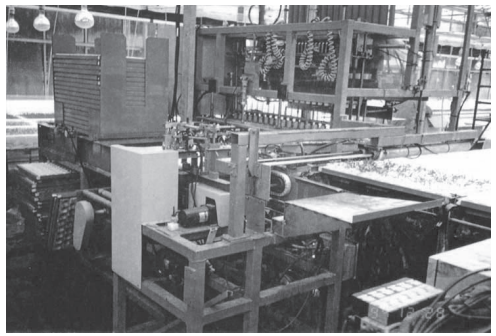

(4)定植ロボット

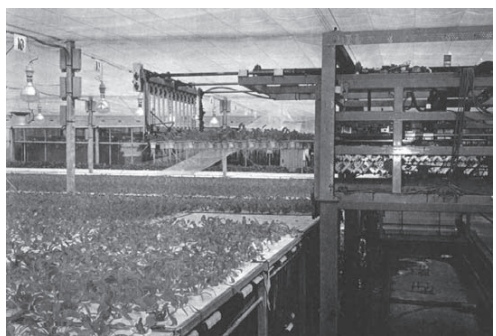

(10中間移植ロボット2

Fig. 5 Machines and robots for automated plant factory (By permission of Idemitsu Kosan Co., Ltd.)
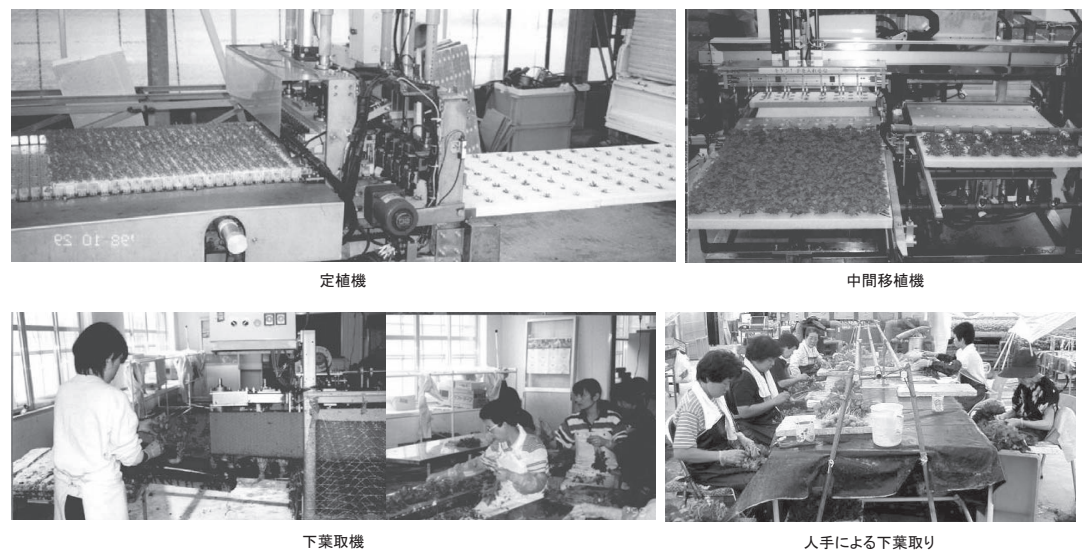

Fig. 6 Machines for hydroponics produces Japanese honewort (By permission of M Hydroponic Research Co., Ltd.)

Table 1 Rating of automation in each process in leafy vegetable production

\begin{tabular}{|c|c|c|c|c|}
\hline \multirow[t]{2}{*}{ 工程・機械 } & \multicolumn{3}{|c|}{ 機械化の目的·必要性 } & \multirow[t]{2}{*}{ 補記 } \\
\hline & 収量増 & 軽作業化 & 安定生产 & \\
\hline ウレタン浸水機 & & $\Delta$ & & 日産 1,000 株では不要, 大規模生产向き \\
\hline 播種機 & & $\Delta$ & & 日産 1,000 株では不要, 大規模生産向き \\
\hline 定植機 & & 0 & & 日産 1,000 株では不要, 大規模生産向き \\
\hline 中間移植機 & $\Delta$ & & & 日産 1,000 株では不要, 大規模生産向き \\
\hline スペーシング機構 & $\Delta$ & & & 多段化, フローテイングで対応, 機械化不要 \\
\hline 収穫装置 & & $\Delta$ & & 多段式での上部棚パネルの移動機械化必要 \\
\hline 包装機 & & 0 & 0 & 規模関係なく必要 \\
\hline 箱組立装置 & & $\Delta$ & & 日産 1,000 株では不要, 大規模生产向き \\
\hline パネル洗浄装置 & & 0 & 0 & 目産 1,000 株では不要, 大規模生産向き \\
\hline パネル殺菌装置 & & & 0 & 規模関係なく導入推奨 \\
\hline
\end{tabular}




\section{謝 辞}

本報作成にあたり (有) ハイテクファーム松村秀雄氏, 九 州電力 (株) 総合研究所 生物資源研究センター中原光久 氏, 元出光興産 (株) 田中功夫氏, 元 $M$ 式水耕研究所村 井信二氏に協力をいただた. ここに記して心より深謝する.

\section{参考文献}

1）高辻正基. 植物工場の基礎と実際. 裳華房, 東京. 1-140. 1996.

2）須永昌博. スウェデポニック式植物工場. In : 日本植物 工場学会 SHITA REPORT 15：44-57. 1999.

3) 田本 均. 川鉄ライフ植物工場の開発動向と実施例. In：日本植物工場学会 SHITA REPORT 14:30-36. 1998.

4）田中功夫. 太陽光利用型植物工場の経済性分析. In : 日本植物工場学会 SHITA REPORT 9：19-27. 1995.
5）田中功夫. GA 型植物工場の開発. In : 日本植物工場 学会 1995 年大会 (東京) 講演要旨集. 東京. 8 月 1 日. 1-12. 1995.

6) Isao Tanaka. Development of Plant Factory. In: 日本 植物工場学会 1996 年大会 (北海道) 講演要旨集. 札 幌. 7月 23 日-24日. 158-161. 1996.

7）高橋 宏, 中村謙治, 小倉東一. スペーシング式栽培シ ステムの開発. In: 農業環境工学関連 3 学会 1997 年 合同大会 (京都) 講演要旨集. 京都. 6 月 6 日 -8 日. 388-389. 1997.

8）高柳栄夫. トータルシステムによるローコスト全人工型植 物栽培. In: 日本植物工場学会 SHITA REPORT 16 : 55-62. 2000.

9）椛一喜, 北原上雄, 中原光久. 野菜工場における 播種一育苗自動化装置の開発. In : 日本植物工場学 会 1995 年大会 (東京) 講演要旨集. 東京. 8 月 1 日. 41-42. 1995.

10）近藤 直, 門田充司, 野口 伸. 農業ロボット ( II ).コ ロナ社, 東京. 158-161. 2006.

11）堀部和雄. 植物工場における自動化. In :日本植物工 場学会 SHITA REPORT 6:15-22. 1993. 